\title{
Impact and Effectiveness of "Watershed Development Programmes" in Education and Health in Keonjhar District of Odisha: A Critical Analysis
}

\author{
Rasmi Ranjan Puhan ${ }^{1}$, Lakshmipriya Malla ${ }^{2}$ \\ Assistant Professor, KIIT School of Social Sciences, (KISS) Bhubaneswar, Odisha \\ Assistant Professor, KIIT School of Social Sciences, (KISS) Bhubaneswar, Odisha
}

\begin{abstract}
The present paper intends to analyse the IWM Programmes implemented by government in Keonjhar District of odisha Named "Khidikhidi Nala Micro-Watershed" of Telkoi block and its various impact on the social-economic background and the educational status of the family residing in that areas. The present study used the survey method to collect data from different primary and secondary sources and taken Keonjhar District as sample and analyse the data accordingly. To analyse the above situation three objectives are made by the researchers like: To highlight different interventions implemented in Odisha, To assess the impact of the interventions on livelihood system and household food security of the poor and marginalized, To examine the impact of interventions on crop production/productivity, cropping systems/cropping intensity, farm / nonfarm employment and income etc., To determine the impact of interventions on health and education status of the people. At the same time same numbers of research questions are framed to make the analysis fruitful. After a marathon analysis researchers found that: The implemented watershed programme develops the socio-economic status of the people in that area in the same time the particular intervention develops the employment scenario significantly of the area. This watershed programme also helps to reduce the skilled labour migration as well as the migration of the general tribal people migration to the urban city area. Along with above findings also it was found that the intervention developed the bio-diversity scenario in fragile ecosystem of that particular area like: soil conservation, land conservation, vegetative index or greenery and reduced runoff etc. In last we can conclude that the particular intervention has an influence in different sectors (education, health, soil and land conservation, along with other positive environmental effects.
\end{abstract}

Keywords: IWMP, Khidikhidi Nala Micro-Watershed, bio-diversity, keonjhar, odisha, reduced runoff, interventions, DPR, etc.

\section{INTRODUCTION}

In the present day in India there are many serious problems combating the per capita, along with the problems i.e. decreasing cultivated land and fresh sufficient water availability are the major along with soil erosion and land degradation which leads to create the threatens in the field of environment, food, social and economic security in the country. In this juncture we should know that land and water development cannot be considered independently both will develop together for the sustainability of our country in general and rain fed areas in particular. In the country like India there are many watershed interventions demonstrated in different areas and found impossible i.e. without proper active and hearty participation of the local community a long term and sustainable solution cannot be possible for land and water resources development. Generally watershed interventions leads to sustainable development when both the natural resources like land and water develop together which able to provide a sustainable production system to the rain fed areas, even if a small natural drainage system. So with above description here now needed a comprehensive and a new paradigm for management of land, water and other biomass resources with focusing on social and institutional aspects with following a "bottom-up" approach, in the same time with proper planning and administration. With following this approach there are large number of watershed programmes are now implemented for productivity enhancement.

The real and proper development of the watershed programmes will be possible when we will conscious about the soil and water conservation. The soil and water conservation also leads to the development of micro-scale water resources along with other number of environmental protection, production and livelihood support interventions.

1 Corresponding Author: rasmi.lakshmi@gmail.com 


\section{American Research Journal of Humanities and Social Sciences, Volume 1, Issue1, Feb-2015 ISSN 2378-7031}

The natural resources like water and land are the most crucial input for bringing the ecological, social and economical revolution and also treated as catalyst for any types of development. With this value one of the most comprehensive planning is necessary to execute the watershed programmes properly at micro level because this is the foundation stone for any types of sustainable production system, also a proper conservation, and management is necessary. Now a days the importance of watershed management programmes increasing particularly as a system approach with the aim of improve the livelihood of people which is one of the millennium development goal along with conservation and regeneration of the natural resources. In the same time the present role and proper participation of local community is necessary to ensure the success and sustainability of watershed programmes which is also worldwide accepted.

During last two to three decades it was found that there were several innovative approaches and planning used with the aim of involving the local people in every phases of development, the approaches like: top-to-down, planning from below, bottom-to up, micro level planning as well as multilevel planning, amongst all bottom-to up planning is mostly used now due to two reasons i.e. firstly the development plan proposed here should desirable for the people and secondly the aim/objectives proposed must be related to the needs and interest of the local community, but the involving scenario is still now unchanged.

No doubt in the present over populated situation the intervention relating to natural resources are immense necessity, but the one type of interventions alone cannot sufficient for poverty elimination from our country this is because in the intervention area there are residing more number of households who are landless. So in this juncture special type of interventions and approaches are needed to provide opportunity to use fairly the natural resources.

In this situation IWMP interventions now mostly helpful for small and marginal farmers as well as for landless and asset less workers with emphasizes different sectors like integration of natural resource management, productivity, better livelihood options \& income through farming system which is the ultimate aim of watershed programmes in particular national development in general. The particular intervention focuses on water resources conservation in the implemented area, frequent monitoring the recharge structures, social management mechanism, sensitizing the users for proper utilization of available resources, sense of ownership along with efficient \&effective operation\& maintenance of innovative structures. Which will undoubtedly able to change the scenario of locality with particular reference to the economics, health and educational sectors.

Thus the ultimate objective of this programme is to develop natural resources based on sustainable productivity, improve standard of living of poor farmers and landless labourers and to restore the ecological balance along with the development of health and educational area. Keeping the above view, the massive watershed development programme for the rain fed area has been launched under different schemes.

Khidikhidi Nala Micro-Watershed comprises of one village namely Tungurbahal. The village is in the Jagmohanpur G.P of Telkoi block. The village has been named basing the word 'TUNGUR' \& 'BAHAL' that means small bit of upland surrounded by low land. Tribes like 'Bhuyan' first migrated to this area and started to live in the major Tungurs . Afterwards some other tribes like 'Juanga, Gonda and Munda came and live in different Tungurs. All these Tungurs were collectively named as 'Tungurbahal'. The village is dominated by ST communities. 'Bhuyan' is the major tribe in the village. 'Juanga' and 'Gonda' are other two tribes of the village.

\section{WATERSHED MANAGEMENT EMPHASIZES}

Management of natural resources

Micro enterprising

$>$ Farming system

$>$ Productivity

$>$ Accountability

$>$ Monitoring \& Evaluation System

$>$ Responsibility

$>$ Sustainability

\subsection{Review of Related studies}

Effective use of land and water is fundamental to growth and sustainable development. The concept of watershed management has evolved to ensure effective use of both natural and social capitals. Thus, the watershed 


\section{American Research Journal of Humanities and Social Sciences, Volume 1, Issue1, Feb-2015}

ISSN 2378-7031

development programmes include land, water and human resources as essential components. The watershed programme is primarily a land based programme, which is increasingly being focused on water, with its main objective being to enhance agricultural productivity through increased in situ moisture conservation and protective irrigation for socio-economic development of rural people (Joshi, et al. 2004, 2006). It is realized that sustainable development is synonymous to maintenance of productivity of natural resources and maintenance of ecological equilibrium. Kushwaha and et al. (2010, p.1479) noted that the concept of sustainable development has received much needed impetus after the Rio Conference in June 1992. The watershed approach is a system-based approach that facilitates the holistic development of agriculture, forestry and allied activities in the proposed watershed. Watershed Development Programmes (WDPs) have been accorded high priority in India's development plans (Singh, 1991). These programmes have been initiated in India to improve and sustain productivity and the production potential of the dry and semi arid regions of the country through the adoption of appropriate production and conservation techniques. The WDP approach seeks to improve and develop all types of lands-government, forest, community and private lands- that fall within a particular watershed. It is a holistic approach to improve and develop the economic and natural resource base of dry and semiarid regions (Ninan and Lakshmikanthamma, 2001). The overall attributes of the watershed development approach, by and large, are three fold, viz. promoting economic development of the rural area, employment generation, and restoring ecological balance (DoLR, 2006). There had been a tendency for proliferation of activities with special area, rural development and employment programs. Departments namely agriculture, forests, rural development, National Waste Land Development Board and voluntary organizations are working on different programs like soil conservation, land shaping and development, minor irrigation, silvipasture, social or farm forestry and a forestation (Vaidyanathan, 1999). Studies by Farrington, et al (1999), Deshpande and Ratnareddy (1991), Kerr et al (2000), Vaidyanathan (1999, 2006), Reddy and Dev (2006), Biswas, et al (2005), Pascual, et al (2009) and others have discussed several issues in watershed development programmes. They have covered policy related issues, institutional drawbacks, implementation issues, community and participation issues, etc. Despite the fact that there are large numbers of issues already covered, the research scope in the issue of watershed management is tremendous. Participatory approaches of watershed management, emphasis on decentralized approach or bottom up approach, etc. are widely discussed by Farrington (1999), Yugandhar, et al (1999) Kerr (2000) D" silva Emmanuel and Sudha Pai (2003) and Vaidyanathan (2006) amongst others. All these studies have stressed importance of proper institutional mechanism both at the ground level and at the top level. Some of the authors have also talked about the issues of equity in distribution and lack of inclusiveness.

\subsection{Rationale of the study}

From the last two decades watershed management programmes are given fully priority for management of natural resources in over populated country like India. The particular interventions are not only developing our economic condition, health condition and education situation with contributing to the livelihood security but also protect and conserve the natural resources along with purifying the environment. But it is one of the matters of fact that before implemented many watershed management programmes were not achieved what these were wanted to achieve with particular reference to soil and water conservation. The consequences like that because the local intended beneficiaries were not involved with proper percentage as well as intention within the programme. After comprehensively analysis of the situation and failure it was cleared that community participation is one of the basic criteria or fundamental necessity for the successful implementation of the watershed management programmes in the area, then the new approach was came into existence that "Integrated Watershed management Programmes" where various services and resources are required for the successful implementation. In this process various natural resources are used like land, different goods, as well as human capital for its sustainable development. Thus the integrated programme must influence the sector like socio-economic, health as well as the sector of education. "Khidikhidi Nala Micro-Watershed" of Telkoi block in Kendujhar district has been identified under "Integrated Watershed Management Programme"(2009-10) aiming at holistic development of the area basing on current needs and aspiration of the people. "The Detailed Project Report" (DPR) has been prepared after identifying the major issues, carefully analyzing the problems and developing intervention strategies with optimum utilization of resources for maximum benefits for the local communities pertaining to both natural as well as non-land based livelihood aspects.

The Khidikhidi nala watershed management is a project report from the Odisha watershed development mission which emphasizes the planning process and Implementation, Monitoring \& Evaluation Mechanism for the geographical defined watershed including the analysis, action and implementation of the plan. The DPR provides a road map to help identifying the problems, set goals and implementation. 


\section{American Research Journal of Humanities and Social Sciences, Volume 1, Issue1, Feb-2015 ISSN 2378-7031}

Due to undulating topography and steep slopes and coarse to medium sedimentary materials, the area is commonly subjected to soil and water erosion hazards. Uncontrolled grazing has resulted in reduction in vegetation and acceleration in erosion. The mounting pressure on arable and non arable land due to increasing human and animal population has resulted environmental degradation. The village is socio-economically highly backward. In order to enhance and stabilize production through improved technology and efficient use of natural resources for overall development of the inhabitants of the area, the village needs to be brought under "Integrated Watershed management Programme". In this juncture here the researchers wanted to know the effectiveness of this implemented programme on various sectors like: education, health, productivity and socio-economic background etc. with taking the following issues and objectives.

\subsection{Issues in Hand}

1. What are the IWM Programmes going on in Odisha along with khidikhidi nala Micro-Watershed?

2. Whether the intervention has any impact on livelihood of Tungurbahal villagers?

3. Whether it helps the people on their crop production, farm and employment?

4. Whether it has any impact on their educational as well as their health condition?

\subsection{Objectives}

The present study intends to highlight with addressing the following objectives

1. To highlight different interventions implemented in Odisha and specially Khidikhidi Nala Micro-Watershed,

2. To assess the impact of the interventions on livelihood system and household food security of the poor and marginalized,

3. To examine the impact of interventions on crop production/productivity, cropping systems/cropping intensity, farm / nonfarm employment and income etc.,

4. To determine the impact of interventions on health and education status of the people.

\section{Methodology}

Descriptive survey method used in the study as the investigators tried to get information about more than one variable also with better understanding of perceptions of stakeholders (Hittleman and Simon, 1997). Through this method information about conditions, situations and events that occur in the present can be obtained (UNESCO, 2005). Therefore, in the present study the investigator used this method to explore all possibilities to measure the impact and effectiveness of Khidikhidi Nala Micro-Watershed on tungurbahal villagers on their economic, education and their health status.

\subsection{Secondary data collection}

The sources of secondary data are the published and unpublished reports. Data from secondary sources were gathered from books, articles, journals, published reports, and Government documents. Quantitative information with regard to current impact, issues on Integrated Watersheds Management Programmes in odisha in general and in keonjhar district tugurbahal village in particular.

\section{DISCUSSION}

\subsection{Western Orissa Rural Livelihood Project}

The Western Orissa Rural Livelihoods project (WORLP) is a ten-year project implemented by the Orissa Watershed Development Mission (OWDM) of Government of Orissa and funded by the UK Department for International Development (DFID). The project started in the year 2000 in the two districts - Bolangir (14 blocks) and Nuapada (5 blocks) and in January 2004 expanded to the new districts of Bargarh (4blocks) and Kalahandi (6 blocks) Government of India (2007).

The project outlay is Rs. 230 Crores, out of which 140 crores are available as Financial Aid for implementing the Watershed and Watershed Plus activities. Rs. 90 Crores is available as Technical Cooperation fund for technical support, Capacity Building, monitoring and evaluation, project management etc. Theoretically, investment made by WORLP in a MWS of $500 \mathrm{Ha}$ is 47.5 lakhs. The cost norm of Rs. 6000 per hectare is being followed in implementing the Watershed activities, while Rs. 3500 per hectare is provided towards Livelihood components. 


\section{American Research Journal of Humanities and Social Sciences, Volume 1, Issue1, Feb-2015 ISSN 2378-7031}

WORLP adopts a "watershed plus" approach, building on Government of India watershed guidelines with additional resources targeted on the poor and marginalized.

The project follows a sustainable rural livelihoods strategy, which takes a holistic view of the assets on which rural people base their livelihoods. The strategy recognizes that natural resource interventions are necessary but not sufficient for poverty elimination; and that in areas of great inequality, special approaches are now necessity to enable the common poor man to overcome access barriers to natural resources. The project supports and follows GoI's Watershed guidelines, as well as the extra resources for "watershed plus" activities as capacity building, minor irrigation, drinking water, and livelihood initiatives for the poorest. The watershed plus component has an additional Rs. 3,500/- per hectare for promoting livelihoods among poorest in the project areas. The project places a strong emphasis on broadening the scope of watershed development activities to ensure that development responds to the needs and priorities of the poor. The project includes four elements to address weaknesses in watershed projects:

Additional resources for activities beyond the scope of the watershed guidelines e.g. irrigation, drinking water, sanitation, forestry, micro

Capacity building for vulnerable groups.

$>$ Strengthening the government staffing structure and capacity building to promote convergence of government rural poverty interventions;

Focusing on enabling policies (e.g. access to non-timber forest products).

The project seeks to bring benefits to poor groups, rather than confining itself to maximizing overall income in the area. The project analyses the constraints and opportunities facing vulnerable groups and uses participatory micro planning as a tool, which reflects the livelihood needs of the poorest. The project has supported investments prioritized through such planning to improve the productivity of land, provision of water and improve drinking water and sanitation. For the poorest groups it is promoting micro credit and non-farm activities. It has been strengthening the capacity of government organisations, local government and NGOs to work together in addressing poverty.

At the State level, the Orissa Watershed Development Mission (OWDM) is the Nodal Agency and is responsible for planning, implementing and monitoring the project. At the District level, the Project Director, Watersheds is responsible for project implementation while the Project Implementing Agency (PIA) facilitates implementation of the project at the Watershed level. In each block, one Project Implementing Agency (PIA) responsible for ten micro watersheds is implementing the project At the State level, a Project Support Unit (PSU) consisting of Subject Matter Specialists supports the Watershed Mission, while at the District level Capacity Building Team (CBT) consisting of 4 - 5 Subject Matter Specialists supports the Project Director, Watersheds. Apart from the Watershed Development Teams, which are available with the PIA under normal Watershed programmes, an extra Livelihood Support Team (LST) is provided to the PIAs at the Watershed level.

\subsection{Orissa Tribal Empowerment And Livelihood Project}

Orissa Tribal Empowerment and Livelihoods Programme (OTELP) is a watershed based livelihood promotion program supported by the International Fund for Agricultural Development (IFAD), Department for International Development (DFID), World Food Programme (WFP), Govt. of India and Govt. of Orissa. The programme covers the 30 most backward blocks with tribal concentrations in seven districts of Southern Orissa namely Gajapati, Kalahandi, Kandhamal, Koraput, Malkangiri, Nawarangpur and Rayagada Government of India (2007). The entire region is hilly and forested and located along the eastern fringes of the Eastern Ghats in the State, populated substantially by the Scheduled Tribes. Most of the Project villages are remote and are almost entirely populated by tribal people. Tribal people here subsist on a patchwork livelihood comprising of shifting cultivation (slash and burn cultivation); low intensity rain-fed agriculture in the plains along streams and on terraced hill slopes; gathering of forest produce, livestock rearing, including small ruminants and backyard poultry; and wage earnings as unskilled workers locally as well as through migration to distant places.

In the current financial year another 65 projects were approved (610 MWS) for treatment of 3, 35,979 ha under the IWMP project. By the end of 14th Plan period total number of 12037 of micro-watersheds is to be taken up into action. For the implementation of these projects assuming the cost sharing of 90:10 between the Govt. of India and Govt. of Odisha with the funds involvement of 6499.98 crores including the state share of 722.22 crores, it is a huge attempt towards natural resource management can touch the apex of its goal by effective participation of its community (Saho. S. And Dash. A (2013). 
American Research Journal of Humanities and Social Sciences, Volume 1, Issue1, Feb-2015 ISSN 2378-7031

Number of Micro Watershed implemented under different schemes

\begin{tabular}{|c|c|c|c|}
\hline Scheme & Districts & Number of Area & MWS in ha \\
\hline IWDP & 23 & 1046 & 544330 \\
\hline DPAP & 8 & 1319 & 667800 \\
\hline NWDPRA & 30 & 885 & 754713 \\
\hline EAS & 13 & 596 & 328562 \\
\hline ACA & 8 & 314 & 167616 \\
\hline RVP & 7 & 29 & 9720 \\
\hline WORLP & 4 & 290 & 147670 \\
\hline OTELP & 4 & 136 & 63678 \\
\hline KBK & 8 & 150 & 75000 \\
\hline Special Plan & 7 & 100 & 50000 \\
\hline RKVY & 112 & 4865 & 2809089 \\
\hline TOTAL & & & \\
\hline
\end{tabular}

Source: $O W D M$

\subsection{Khidikhidi Nala Micro-Watershed}

"Khidikhidi Nala Micro-Watershed" of Telkoi block in Kendujhar district has been identified under "Integrated Watershed Management Programme"(2009-10) aiming at holistic development of the area basing on current needs and aspiration of the people.

"The Detailed Project Report" (DPR) has been prepared after identifying the major issues, carefully analyzing the problems and developing intervention strategies with optimum utilization of resources for maximum benefits for the local communities pertaining toboth natural as well as non-land based livelihood aspects.

A Watershed Plan is a document that results from the watershed planning process and provides assessment and management information for a geographically defined watershed, including the analysis, action, and implementation of the plan. The plan provides a road map to help in identifying the problems, setting goal and implementing solution for the benefit of the watershed dwellers.

Micro level planning is an essential process for any watershed project. It is an empowering tool , as local community come together to understand their environment, resource and process governing the socio-economic perspective and in so doing learn to design a participatory plan to generate the resource base to optimize livelihood options.

\subsection{Objectives of Watershed Planning:}

To understand the issues and opportunities of Natural, Human and Animal resources.

Conservation of moisture in the watershed area for optimal utilization.

To prepare a strategic action plan for a stipulated time period to develop operational annual action plan based on the changing needs and situation arising that of.

To check soil erosion.

To recharge ground water.

To support the vulnerable community to raise above the poverty line.

To enhance capacity of communities to identify and actualize asset building and livelihood opportunities.

To identify the village level institution and strengthening them to address the issues relating to vulnerable community through gender empowerment and improved access and control over resources.

To create ownership among the communities and to participate and share the responsibilities during planning, implementation, post project follow up phases for sustainability. 
American Research Journal of Humanities and Social Sciences, Volume 1, Issue1, Feb-2015

ISSN 2378-7031

4.5. Problem Topology and Solutions from this Project

\begin{tabular}{|c|c|c|c|c|c|}
\hline Issues & $\begin{array}{c}\text { Problem } \\
\text { area }\end{array}$ & Constraints & Solutions & Project support & $\begin{array}{c}\text { Likely } \\
\text { benefit/beneficiaries }\end{array}$ \\
\hline $\begin{array}{l}\text { Water } \\
\text { resource }\end{array}$ & $\begin{array}{l}\text { *Surface } \\
\text { water } \\
\text { Source } \\
\text { *Ground } \\
\text { water } \\
\text { source }\end{array}$ & $\begin{array}{l}\text { *Poor irrigation } \\
\text { potentiality } \\
\text { of WHS and } \\
\text { water bodies. } \\
\text { *Siltation of } \\
\text { water bodies } \\
\text { * Erratic rainfall } \\
\text { * Lack of } \\
\text { vegetation }\end{array}$ & $\begin{array}{l}\text { *Repair of } \\
\text { existing water } \\
\text { bodies. } \\
\text { *Creation of new } \\
\text { water bodies } \\
\text { *Different soil } \\
\text { and water } \\
\text { conservation } \\
\text { measures to } \\
\text { recharge ground } \\
\text { water. } \\
\text { *Field bunding } \\
\text { *Farm pond and } \\
\text { ring wells in the } \\
\text { lower reach } \\
\text { to tap the ground } \\
\text { water }\end{array}$ & $\begin{array}{l}\text { *Repair of } \\
\text { existing } \\
\text { W.H.S and ponds } \\
\text { *Field bunding } \\
\text { and } \\
\text { contour bunding } \\
\text { *Percolation tank } \\
\text { in } \\
\text { the upper reach } \\
\text { *Ring wells and } \\
\text { farm } \\
\text { ponds in the } \\
\text { lower } \\
\text { reach }\end{array}$ & $\begin{array}{l}\text { *Increase in ground } \\
\text { water table. } \\
\text { *Increase production } \\
\& \text { income } \\
\text { *All farmers }\end{array}$ \\
\hline$C P R$ & $\begin{array}{l}\text { *Awareness } \\
\text { *Degradation } \\
\text { of } \\
\text { forest }\end{array}$ & $\begin{array}{l}\text { *Encroached by } \\
\text { watershed } \\
\text { dwellers } \\
\text { *Poor soil status } \\
\text { *More porn to } \\
\text { grazing }\end{array}$ & $\begin{array}{l}\text { *Mutual solution } \\
\text { for possible } \\
\text { measures } \\
\text { *Pasture land } \\
\text { development } \\
\text { *Rejuvenation of } \\
\text { degraded forest } \\
\text { Formation of } \\
\text { VSS }\end{array}$ & $\begin{array}{l}\text { *Plantation of } \\
\text { multiple } \\
\text { species through } \\
\text { Forest } \\
\text { Deptt. } \\
\text { *Pasture land } \\
\text { development for } \\
\text { community } \\
\text { fodder } \\
\text { bank }\end{array}$ & $\begin{array}{l}\text { *Increase the } \\
\text { income of } \\
\text { watershed dwellers } \\
\text { * Meet the basic need } \\
\text { like food, fodder, } \\
\text { fuel and NTFP } \\
\text { *All HH }\end{array}$ \\
\hline $\begin{array}{l}\text { Drinking } \\
\text { Water }\end{array}$ & $\begin{array}{l}\text { *Drinking } \\
\text { water quality } \\
\text { - Availability } \\
\text { - Low water } \\
\text { table }\end{array}$ & $\begin{array}{l}\text { - During rainy } \\
\text { season drinking } \\
\text { water sources get } \\
\text { contaminated } \\
\text { - Symptom of } \\
\text { high level of Iron } \\
\text { and fluoride } \\
\text { content in the } \\
\text { water } \\
\text { - Hand pumps get } \\
\text { dried during } \\
\text { summer due to } \\
\text { low water } \\
\text { table } \\
\text { - Defunct of hand } \\
\text { pumps } \\
\text { - Low ground } \\
\text { water table }\end{array}$ & \multicolumn{2}{|c|}{$\begin{array}{l}\text { - Repair of platform with drain and } \\
\text { soak pit } \\
\text { - Water testing of drinking water } \\
\text { sources } \\
\text { - Repairing of defunct hand pumps / } \\
\text { wells } \\
\text { through local initiatives } \\
\text { - Ground water recharge through } \\
\text { various } \\
\text { water conservation measures }\end{array}$} & $\begin{array}{l}\text { All categories of } \\
\text { Households }\end{array}$ \\
\hline Education & $\begin{array}{l}\text { *School } \\
\text { child drop } \\
\text { out } \\
\text { *Irregular } \\
\text { attendance of } \\
\text { school } \\
\text { teachers }\end{array}$ & $\begin{array}{l}\text { *Available } \\
\text { School for higher } \\
\text { study } \\
\text { is far distance } \\
\text { from the village } \\
\text { *Lack of } \\
\text { awareness among }\end{array}$ & \multicolumn{2}{|c|}{$\begin{array}{l}* \text { Awareness generation among parents } \\
* \quad \text { Organize gender sensitize } \\
\text { programme } \\
* \text { Activate village education committee } \\
* \text { Livelihood improvement measures to } \\
\text { reduce migration }\end{array}$} & $\begin{array}{l}\text { *Parents \& Children } \\
\text { up to } \\
14 \text { years } \\
* \text { All categories of } \\
\text { Households } \\
* \text { Migrating families }\end{array}$ \\
\hline
\end{tabular}


American Research Journal of Humanities and Social Sciences, Volume 1, Issue1, Feb-2015 ISSN 2378-7031

\begin{tabular}{|c|c|c|c|c|c|}
\hline & * Awareness & $\begin{array}{l}\text { parents } \\
\text { *Gender } \\
\text { disparity in the } \\
\text { society } \\
\text { * Migration } \\
\text { * Poor economic } \\
\text { condition }\end{array}$ & & & \\
\hline Health & $\begin{array}{l}* \text { Around } 90 \\
\% \text { people } \\
\text { suffer } \\
\text { from malaria } \\
\& \text { other } \\
\text { common } \\
\text { diseases } \\
* \text { Poor } \\
\text { village } \\
\text { sanitation } \\
\text { *Women } \\
\text { health issues } \\
\text { ignored } \\
* \\
\text { Institutional } \\
\text { support } \\
* \\
\text { Malnutrition }\end{array}$ & $\begin{array}{l}\text { *Lack } \\
\text { awareness of } \\
\text { preventive } \\
\text { measures } \\
\text { *Unsafe drinking } \\
\text { water } \\
\text { *Poor water } \\
\text { drainage system } \\
\text { \& } \\
\text { water logging at } \\
\text { sources } \\
\text { drinking } \\
\text { water } \\
\text { *ANM is not } \\
\text { visiting regularly } \\
\text { to the } \\
\text { village } \\
\text { *Angnawadi is } \\
\text { defunct } \\
\text { *Lack } \\
\text { awareness on } \\
\text { women health } \\
\text { problems } \\
\text { preventive } \\
\text { measures. } \\
\text { *Non availability } \\
\text { of nutritional } \\
\text { food High health } \\
\text { * Hof } \\
\text { expenses } \\
\text { *Poor economic } \\
\text { condition }\end{array}$ & \multicolumn{2}{|c|}{$\begin{array}{l}\text { *Awareness on preventive health care. } \\
\text { *Organising health camps } \\
\text { * Strengthening village } \\
\text { institutions to monitor } \\
\text { / ensuring the availability of ANM \& } \\
\text { Anganwadi } \\
\text { services } \\
\text { *Improving drainage system of waste } \\
\text { water and } \\
\text { sunken pit near tube wells \& around } \\
\text { water logged } \\
\text { areas. } \\
\text { *Training on women health care } \\
\text { *Promotion of use of impregnated } \\
\text { mosquito net } \\
\text { *Promotion of kitchen garden } \\
\text { *Promote low cost latrine through } \\
\text { RWSS } \\
\text { *Promotion of low cost water filter and } \\
\text { smoke less } \\
\text { chulla. }\end{array}$} & $\begin{array}{l}* \text { All categories of } \\
\mathrm{HH} \\
* \text { Women \& children }\end{array}$ \\
\hline Agriculture & $\begin{array}{l}\text { *Low } \\
\text { productivity } \\
\text { *Irrigation } \\
\text { *Finance } \\
\text { *Technical } \\
\text { guidance } \\
\text { *Availability } \\
\text { of } \\
\text { in puts }\end{array}$ & $\begin{array}{l}\text { *Erratic Rainfall } \\
\text { and frequent } \\
\text { drought } \\
\text { *Poor application } \\
\text { of FYM } \\
\text { *Lack of agril- } \\
\text { inputs } \\
\text { *Labour problem } \\
\text { *Less use of } \\
\text { fertilizers } \\
\text { * More diseases } \\
\text { pest attack } \\
\text { *Undulated land } \\
\text { *Poor risk } \\
\text { bearing capacity } \\
\text { *Lack of } \\
\text { knowledge }\end{array}$ & $\begin{array}{l}\text { *Run off } \\
\text { management, } \\
\text { timely sowing of } \\
\text { crops } \\
\& \text { use of drought } \\
\text { resistant varieties } \\
\text { *Motivating } \\
\text { farmers } \\
\text { summer for } \\
\text { ploughing } \\
\text { and organic } \\
\text { manures } \\
\text { *Contact with } \\
\text { Agriculture deptt. } \\
\text { *Use of organic } \\
\text { and inorganic } \\
\text { fertilizers }\end{array}$ & $\begin{array}{l}\text { *Renovation } \\
\text { existing } \\
\text { water bodies and } \\
\text { construction of } \\
\text { new } \\
\text { water bodies } \\
\text { *Field bunding } \\
\text { *Providing agril- } \\
\text { inputs } \\
\text { *Dry } \\
\text { farming } \\
\text { practices } \\
\text { *Training on crop } \\
\text { diversification } \\
\text { and } \\
\text { composting } \\
\text { * Mixed cropping }\end{array}$ & $\begin{array}{l}\text { *Soil and water } \\
\text { conservation } \\
\text { *Increase in } \\
\text { production } \\
\text { *Enhance income \& } \\
\text { quality of life } \\
\text { *User group \& } \\
\text { watershed dwellers }\end{array}$ \\
\hline
\end{tabular}




\begin{tabular}{|c|c|c|c|c|c|}
\hline & & *Acidic & $\begin{array}{l}\text { *Seed treatment } \\
\text { with bio-fertilizer } \\
\text { *Timely control } \\
\text { of diseases and } \\
\text { pest and use } \\
\text { organic pesticides } \\
\text { *Use of high } \\
\text { yielding varieties, } \\
\text { crop } \\
\text { diversification } \\
\text { and use the } \\
\text { residual moisture } \\
\text { for legumes }\end{array}$ & $\begin{array}{l}\text { *Soil reclamation } \\
\text { *Vermi } \\
\text { composting } \\
\text { *Providing farm } \\
\text { implements } \\
\text { *Training on } \\
\text { INM and } \\
\text { IPM and } \\
\text { exposure visit } \\
\text { *Crop } \\
\text { diversification }\end{array}$ & \\
\hline Horticulture & *Awareness & $\begin{array}{l}\text { *Horticulture is } \\
\text { not } \\
\text { recognized as a } \\
\text { source of } \\
\text { livelihood } \\
\text { because of late } \\
\text { return of } \\
\text { investment of } \\
\text { fruit } \\
\text { plant } \\
\text { *Less awareness } \\
\text { on } \\
\text { Horticultural } \\
\text { promotion }\end{array}$ & $\begin{array}{l}\text { *Create } \\
\text { awareness among } \\
\text { villagers on } 2 \text { tier } \\
\text { production system } \\
\text { for an early } \\
\text { return. } \\
\text { *Promotion of } \\
\text { agro horticulture } \\
\text { *Promotion of } \\
\text { vegetable } \\
\text { cultivation } \\
\text { *exposure }\end{array}$ & $\begin{array}{l}\text { *Plantation on } \\
\text { CPR, } \\
\text { private land } \\
\text { *Introduction of } \\
\text { vegetable } \\
\text { cultivation } \\
\text { *Providing pump } \\
\text { set } \\
\text { for } \\
\text { vegetable } \\
\text { cultivation }\end{array}$ & $\begin{array}{l}\text { *Increase in } \\
\text { production \& } \\
\text { income } \\
\text { *All farmers }\end{array}$ \\
\hline
\end{tabular}

Sources: govt. Of Odisha (Odisha Watershed Development Mission-2014)

\subsection{Findings of the study}

1. It was found that the SHG group of that tungurbahal village and the nearby areas have the more participation in the developmental activities than the Non-SHGs people, so here we can say it has the impact on the local people.

2. The particular intervention has one of the great influences on the gender gap in the areas of agriculture as well as has an impact in the socio-economical status of the people; means, their economic condition were developed.

3. As the economical and social status increased then it has a positive impact on the most valuable sector like education, quality health services, non use of witchcraft, changes found in the medical expenses, use of safe and potable drinking water as well as capable to create a congenial healthy atmosphere in the areas.

4. Peoples' participation depend on attitude of the people, the environment they live in, attitude of the government functionaries, government approach, lack of capacities, lack of women's participation and favourable surroundings.

5. It was also seen that the intervention area people used the new water irrigation structures i.e. they dug wells, ponds, WHS and different small water irrigation channels. Also it was noteworthy it will creates the awareness about the people of that areas so then they have created interest towards plantation in their own and government land.

6. It was also evident from their bank passbook and other related savings document now their financial savings changed in a positive increased manner of the people also they invested the money from different areas to get profit from them. In the same time it was also found that the SHGs have more increasing level of capital than their counterpart means non-SHGs.

7. If we will compare the awareness, banking use and establishment of the other community based institution from the project and non-project areas we must get one clearer picture that the intervention areas have more number of community based institution like SHGs and Grain Bank etc. 
8. The influence of the intervention we can measure if we go through their present cropping system as well as their present different varieties within the rain fed areas like it was changed general crops to the financial/ commercial cereals like; cotton, lemon gross, fisheries, poultry and different types of need based vegetables to maintain the scarcity of the areas in particular for our country in general.

9. The recent style of cropping with using modern fertilizers and pesticides is using by then like; using different types of chemical fertilizers, bio-fertilizers and pesticides etc. that means their awareness about the productivity is changed.

10. The particular intervention increased the migration scenario of the watershed areas means it combat the problems of skilled and unskilled labour migration to the particular village to the urban industrial areas because the particular intervention creates the employment opportunities with encouraging and developing the modern approaches of agriculture. Thus the education sector of that village is changed now and all the parents they are sending their children to the schools instead of labour work to the agriculture or to the urban areas, in the same time it was changed the environmental quality of the village as they aware about the environmental pollution, so the plant the trees in the areas, ultimately it leads to the better heath situation of the village.

11. The particular intervention also changed the erotic problem in the field of environment with creating different vegetable index, soil conservation, rain water conservation, land degradation, and changed the fragile ecosystems of odisha in general village in particular. Ultimately the particular intervention helps the odisha's people with provide sustainable outputs, thus it has comprehensively changed the sector like finance, health and education.

\section{SUgGESTIONS}

1. Special planning is needed to train the Marginal farmers and women groups for creating the social community like SHGs, also it is necessary to make separate plan for the landless people to get employment opportunity in the areas.

2. Awareness programmes should be conduct time to time about the merits of watershed programmes along with suitable burning local example to the vulnerable section people so then the programme will strong in the grass root level.

3. Government should organise proper training programme on the topic like; use of pesticides, merits and de-merits of it, bio-fertilizer, different agricultural inputs along with livestock management by different NGO and efficient agricultural agencies.

4. Time to time exposure visits are necessary to motivate the farmers to the near by intervention or may be state level about successful models, which will definitely motivate them along with improve the knowledge of different fields of agriculture in between the members of the village.

5. One of the major problems of this type of interventions is survive after the intervention exit from the areas, so here proper planning is needed to train them as they will maintain their resources of income and manage it properly.

6. Time to time frequent monitoring and inspection needed for the qualitative assessment of the programme along with feedback to the stakeholders, if necessary provide the necessity implementation and remedial by the government or NGOs.

7. Along with the agriculture innovative business system should be introduced by the implemented agencies with taking the present resources for the sustainable development of the people of those areas.

8. Proper planning and execution approach should be made for proper use of natural and human capital of those areas, which will ultimately develop the sustainability of these peoples.

9. Planning like use of non-land based activities can be developing the employment limit of the people along with it is necessary for the sustainability of the project. This planning is special effective for the landless and marginal workers of the area, it will creates the opportunities like wage employment opportunity, combat migration, opportunities to use education as business etc.

10. The most important feature of the project is women empowerment through agriculture and other project related activities, in the same time it should be emphasize how they will more participate in the income generation activities with making community institution, also opportunity should provide to them to take participate proactively in the decision making process. 


\section{CONCLUSION}

Khidikhidi Nala Micro-Watershed management programme has major impact on the sectors like water resources, rural livelihoods, education, health, environment and ecology, thus the scenario of these sectors are developing day by day with a positive manner. Along with above major impact the present watershed management programme has another major impact on changing the surface and groundwater availability during the summer season means in the critical period when there will be no rain in the area. Through the increased surface and groundwater the cropping system can be developed like increasing cropping system, land use system, involving livestock, horticulture, and vegetable production along with the major and valuable impact on the education and health sectors of that area. The watershed programme will impact as increasing productivity of crops which helps to increase the margin profit of the farmers. It also helps to combating the adverse impact of drought and any other natural calamity along with provides more water availability and mare fodder security in this scarcity time. Along with all these thing as the programme is integrated it has the great impact to change the educational scenario of that area and nearby areas as well as it also helps the peoples to aware about the deferent diseases and develop the health situation of that areas.

\section{REFERENCES}

[1] Biswas, A.K. et al. (2005): Integrated Water Resources Management in South and South-East Asia, Oxford University Press, New Delhi.

[2] Deshpande, R.S. and V. Ratnareddy (1991): Watershed approach in fragile Resource Regions-An analytical study of Maharashtra, mimeograph series no.33, Gokhale Institute of Politics and Economics, Pune.

[3] D“ silva, Emmanuel., \& Sudha Pai (2003): „Social Capital and Collective Action: Development Outcomes In Forest Protection And Watershed Development" , Economic and Political Weekly, April 5, 2003.

[4] Farrington, John Cathryn Turton., \& A.J. James (eds) (1999): 'Participatory Watershed Development', Challenges for the Twenty - First Century "e , Oxford University Press, Delhi.

[5] Hittleman, D. R. And Simon, A. J. (1997), Interpreting Educational Research: An Introduction for Consumers of Research, Prentice-Hall, Inc. New Jersey.

[6] Government of India (2007): Report of the Working Group on Natural Resources Management: Eleventh Five Year Plan (2007-2012), Planning Commission, New Delhi.

[7] Govt. of odisha (2014) Khidikhidi Nala Micro- Watershed (IWMP - II), Micro- Watershed Code No: 0408010207250101, watershed development mission, Government odisha Bhubaneswar, pp-52-55

[8] Joshi, et al. (2004): Socio economic and Policy Research on watershed Management in India: Synthesis of Past experiences and needs for future research, ICRISAT, Hyderabad.

[9] Joshi, P.K. et al. (2008): Report no. 46 on Impact of Watershed Program and Conditions for Success, A Meta Analysis Approach, International Crops Research Institute for the Semi- Arid Tropics, Andhra Pradesh.

[10] Kerr, J. et al. (2000): An Evaluation of Dry Land Watershed Development Projects in India, Environment and Production Technology Division, International Food Policy Research Institute 2033, K Street, N.W Washington, D.C. 20006 U.S.A.

[11] Kushwaha, S. P. S. et al (2010): Sustainable Development Planning in Pathri Rao Sub-watershed Using Geospatial Techniques, Current Science, Vol. 98, No. 11,10 June.

[12] Ninan, K.N. and S. Lakshmikanthanthamma (2001): Social Cost-Benefit Analysis of a Watershed Development Project in Karnataka, Vol.30 No.3, Royal Swedish Academy of Sciences.

[13] Pascual, U. et al. (2009): Water Agriculture and Sustainable Wellbeing, Oxford University Press, New Delhi.

[14] Reddy, V. Ratna (2000): Sustainable Watershed Management Institutional Approach, Economic and Political Weekly, September issue.

[15] Saho. S. And Dash. A (2013) Involvement of SHGs in Watershed Management - An Impact Analysis, Orissa review, pp-4950, Bhubaneswar

[16] Vaidyanathan, A. (2006): India's Water Resources: Contemporary Issues on Irrigation, Oxford University Press, New Delhi.

[17] Vaidyanathan, A. (1999): Water Resource Management, Oxford University Press, New Delhi.

[18] Wani, S.P., Sreedevi, T.K., Pathak, P., Singh P. and Singh, H.P. (2001): Integrated Watershed Management through a Consortium Approach for Sustainable Management of Watersheds, 1-2 November 2001, ICRISAT, Patancheru, Andhra Pradesh, India.

[19] Yugandhar B.N., J. Venkateswarlu \& Vijay Kochar (1999): „Watershed Based Development in Arid and Semi-Arid Areas of Andhra Pradesh" , Journal of Rural Development, Vol. 18 No. (3), pp. 471-503 (1999).

[20] UNESCO (2005), Quantitative Research Methods in Educational Planning, UNESCO International Institute for Educational Planning, Paris, France. 